\title{
Managerial views on compulsory unionism in New Zealand
}

\author{
A J Geare*
}

The New Zealand industrial relations literature contains a number of propositions concerning the impact or desirability of having compulsory union membership. This paper discusses the propositions, and reports on the response of a sample of $461 \mathrm{New}$ Zealand managers, examining the significance of their attitudes.

\section{Introduction}

Compulsory unionism, either by statute or by agreement, has played a significant role in New Zealand industrial relations for over half a century. At various stages the views of the New Zealand Employers' Federation (NZEF) on compulsory unionism have been made known. (The NZEF was anti in 1936, but had swung completely to be pro in 1951, 1961, and the 1970's. It had a second swing to again be anti in 1984). However, the views of New Zealand managers have not received much publicity. This paper attempts to redress the problem and is an examination of managerial, as opposed to NZEF, views on compulsory unionism.

Given the number of accounts already in the literature (Szakats, 1972; Howells, 1983; Geare, 1984) most readers will be familiar with New Zealand's experience with compulsory unionism. However it should be noted that from 1936-1961 there was compulsory unionism by law; from 1961-1984 and 1985-present, compulsory unionism "by agreement" (union-management) or, failing that, by majority vote of the workforce. From 1984-5, there was a brief period of voluntary unionism, by law.

This paper examines 7 of the more common propositions in the literature concerning compulsory unionism and discusses the attitudes of a sample of 461 New Zealand managers to those propositions. It also gives the attitudes to the general questions as to whether compulsory unionism should be encouraged, tolerated or discouraged.

\section{Method}

The research study replicates an earlier study undertaken in Australia. It involved sending a multi-faceted questionnaire to 995 managers throughout New Zealand. The managers had been selected by name and position from the New Zealand Business Who's Who 1984-5 using systematic sampling to give a spread of position, seniority and 
organisation size (minimum of 20 employees) and to ensure that only managers, as opposed to non-executive directors, were selected. A total of 506 responses were obtained, of which 461 (46.3 percent of the original sample) were useable. In this way information from a cross section of managers was obtained. A brief description of the sample is given below in Table 1 .

\section{Table 1: Description of sample}

\begin{tabular}{|c|c|c|c|c|c|c|}
\hline Job level & $\%$ & : & $\begin{array}{c}\text { Board } \\
23.2\end{array}$ & $\begin{array}{c}\text { Senior/Staff } \\
69.6\end{array}$ & $\begin{array}{l}\text { Middle } \\
7.2\end{array}$ & \\
\hline Function & $\%$ & $:$ & $\begin{array}{c}\text { General Mgt. } \\
64.9\end{array}$ & $\begin{array}{c}\text { Personnel/I.R } \\
16.3\end{array}$ & $\begin{array}{l}\text { Other } \\
18.9\end{array}$ & \\
\hline Size of Org & $\%$ & $:$ & $\begin{array}{c}>20<100 \\
33.6\end{array}$ & $\begin{array}{c}<1,000 \\
12.8\end{array}$ & $\begin{array}{c}<5,000 \\
15.2\end{array}$ & $\begin{array}{c}>5,000 \\
\quad 6.5\end{array}$ \\
\hline Size of Plant & $\%$ & : & $\begin{array}{c}>20<100 \\
63.8\end{array}$ & $\begin{array}{l}<500 \\
30.4\end{array}$ & $\begin{array}{l}>500 \\
5.9\end{array}$ & \\
\hline Gender & $\%$ & $\begin{array}{l}: \\
:\end{array}$ & $\begin{array}{l}\text { Male } \\
99.3\end{array}$ & $\begin{array}{c}\text { Female } \\
0.2\end{array}$ & $\begin{array}{c}\text { Not Given } \\
0.4\end{array}$ & \\
\hline $\begin{array}{l}\text { Plant has } \\
\text { dealings with } \\
\text { Unions }\end{array}$ & $\%$ & : & $\begin{array}{l}\text { No } \\
15.4\end{array}$ & $\begin{array}{l}\text { Yes } \\
84.6 \\
\end{array}$ & & \\
\hline
\end{tabular}

In this aspect of the study, respondents answered the questions on a 7-point Likerttype scale indicating from strongly disagree to strongly agree their response to 7 propositions regarding compulsory unionism discussed below. In addition they responded to questions as to whether they considered compulsory unionism:

(a) should be encouraged;

(b) should be discouraged;

(c) should be neither encouraged nor discouraged - but tolerated if it occurs.

\section{Propositions concerning compulsory unionism}

The issue of compulsory unionism has often aroused emotional and unthinking reactions. Such matters "have traditionally been regarded as a controversial subject and...still generate a lot of heat" (Cordova and Ozaki, 1980, p.19). A further difficulty in having rational arguments on the desirability or impact of compulsory unionism is that the issue is so dependent on value judgements and the frame of reference of the particula observer. Hence different people will argue not only about the truth or otherwise of statement, but even if in agreement about the truth, may disagree as to the consequences. For example, one proposition is that compulsory unionism reduces union militancy. It is quite possible to either accept or reject the proposition as a matter of fact. If it is accepted, this may be perceived as an argument for compulsory unionism (if the person opposes militancy), or against (if the person favours a militant approach).

As stated above, the paper examines 7 propositions that are supported in the literature and discusses the degree of logic behind each one. The degree of managerial support for these propositions will be presented and discussed. The propositions are that compulsory unionism, (through what was known as "unqualified preference" and is now known as the "union memberships clause"):

\section{(1) will reduce union militancy}

This viewpoint has been argued at around the time of a number of the significant periods in New Zealand's history of compulsory unionism - 1936, 1961 and 1976. There are three aspects to the argument. The first is that most unions should become at least somewhat less militant in that the impact of the militant members becomes lowered by the numbers of apathetic unionists, forced to become members because of the compulsion. Thus a quarterly journal, the Round Table, stated in September 1937 that compulsory unionists "tend rather to "dilute" the militants and so to accentuate the tendency for unions to concern themselves primarily with problems of hours and wage rates rather than with socialism" (Roth, 1973, p.58). This line of argument, in contrast to proposition (2) below, assumes that a union's strength lies in the proportion of strongly committed members, rather than in its size or wealth.

The second aspect is that central union organisations are less militant under compulsory union membership, since the influence of unions on the policy stance of the central organisation depends on their size, and traditionally non-militant unions such as clerical unions and shop assistants gain relatively far more members under compulsory unionism than do militant unions. Woods (1975), observes that when it was suggested that compulsory unionism be abolished in 1961, it was the non-militant unions who were the most concerned, because not only would their memberships be drastically cut but their "voting strength in Federation of Labour conferences...would be equally drastically cut" (p.32). Woods further points out that the NZEF also realised that the proposal for voluntary unionism "would radically alter the balance of power in the Federation of Labour". This viewpoint of the NZEF remained into the 1970's and when the National Opposition stated that if they were returned to power in 1975 they would introduce voluntary unionism, that policy was again attacked. Harbridge and Walsh (1985) report that "The New Zealand Employers Federation warned that any move towards voluntary unionism would strengthen militant unions at the expense of moderate unions, and its president acidly dismissed the proposal as nonsense" (p.195).

The third aspect is that union militancy is often a result of having to demonstrate their "effectiveness" by taking aggressive action to attract and retain members. Hanson $e t$ al. (1982) discusses this point and "the view that the closed shop encourages 'responsible' unions" (p.13). The rationale is, that by not having membership worries, unions can take a longer term, more "mature" viewpoint.

\section{(2) will strengthen the union movement through increased membership}

Hare (1946) although in general critical of compulsory unionism, acknowledged its strengthening effects, pointing out that

It has resulted in a great strengthening of the existing unions, increasing both their membership and their financial strength...and it has at the same time resulted in the unionisation of many small groups of workers who were previously unorganised (p.180).

Hare further points out that compulsory unionism also resulted in a stable, long lasting central organisation - the Federation of Labour. Compared to the previous organisations the Federation marked "a great advance in stability, power and representativeness" (p.187). Geare (1988) has illustrated the dramatic effect compulsory unionism in New Zealand had both on overall union membership growth from 1935- 
1937 (up 188\%) and more particularly on specific unions (such as, shop assistants up $358 \%)$.

Thus, in contrast to the previous proposition, this one assumes that strength basically comes from membership size resulting in increased financial strength (from union dues), and in some circumstances strength is reflected in voting strength on centra organisations. Woods (1963) reports that among union members themselves, an important minority hold:

to the view that compulsory membership saps the initiative and the real to thength and solidarity of a lukewarm, apathetic, and even unsympathetic members (p.131)

(3) will reduce conflict within the workforce

This proposition argues that compulsory unionism reduces intra-workforce conflict, in that union members no longer resent non-members who are seen as "free-riders". Roth (1973) reports an account by the secretary of the Hotel Workers' Association, who asserts that before the introduction of compulsory unionism non-members were subjected to "a that before the introduction of compulsory unionism non-members were subjected to "a
mild form of coercion and intimidation" to force them to join, or else "conditions...were made so difficult on the job that a non-unionist would not stay"(p.124). There is a logical relationship between this proposition and the first - the conflict created by the non-unionists should tend to make unions more militant.

A counter to this proposition could be made that during the brief period of voluntary unionism from 1984-1985 there was relatively little industrial disruption. The then Director of the NZEF stated "The country has now had the experience of voluntary unionism...there has not been industrial mayhem" (Campbell, 1984, p.19). However just after voluntary unionism was introduced in 1984, the point was made (Geare, 1984) that little union action should rationally be anticipated - because an election was forthcoming which Labour had an excellent chance of winning. If re-elected, Labour was certain to revoke the legislation. Any violent action during the run-up to the election would only hurt Labour and favour National.

\section{(4) is an unwarranted infringement on human freedom}

This argument is probably the most emotive concerning compulsory unionism. In a simplistic sense it is true that any compulsion infringes freedom. However, this is not a simple world. As argued below, preventing compulsory unionism also infringes freedom. The issue here is whether the infringement is unwarranted or not, bearing in freedom. The issue here is whether the infringement is unwarranted or not, bearing in
mind the advantages that may accrue from compulsory unionism, and the escape valve for individuals with genuine convictions to be granted conscientious objector status.

The literature on New Zealand industrial relations has many examples of this proposition being discussed as one argument against compulsory unionism (including Szakats, 1972. Roth, 1973; Howells, 1983' and Harbridge and Walsh, 1985) but less from those arguing the point out of conviction. An exception is the paper by the current leader of the Opposition who, when Minister of Labour, strongly argued that compulsory unionism "is a clear infringement on personal freedom" (Bolger, 1983, p.24).

Outside the academic literature, this is the most usual argument put up by those who oppose compulsory unionism. Usually it is done in a way that implies that rejection of this point of view indicates a lack of concern for "freedom of the individual". Thus, when asked why the NZEF had seemingly discovered "individual freedom" after ignoring it for 20 years the then Director replied:

We changed our views. We decided that individual rights had been forgotten for too long in New Zealand. It is fundamentally objectionable for assessors to sit around a table and decide for thousands of people they'd never met, and who had no say in electing them. Fundamentally objectionable (Campbell, 1985, p.19)

There is an interesting observation by Paul Roots (1986), Director of Industrial Relations for Ford (UK), which refers to the British semi-equivalent of the Employers Federation - the CBI (Confederation of British Industry). He states:

The rhetoric of the CBI is also at variance with the views of individual employers. The further one goes from the shopfloor, the more strident become criticisms of the closed shop in terms of a denial of individual liberty. Individual liberty is an upper-class concept. Working people have to get up early, accept shift work, and do as they are told by employers. They have very little freedom, and in their environment the concept of individual liberty has very little meaning. Politicians need to realise the realities of the shopfloor if they are to make the law relevant to industrial relations (p.2).

The above quote hints at the hypocrisy with which some proponents argue for freedom with regards to compulsory union membership, while supporting a lack of freedom in many other work and life activities. Further, it should be noted that a denial of compulsory unionism also denies committed unionists the right not to have to work with free-riders. The issue is thus one of assessing conflicting freedoms and their relative importance in a situation of many restrictions on freedom. It is not, whatever the propaganda, a question of being simply for or against human freedom.

(5) results in unions not bothering to provide good service for their members

The basic rationale for this argument is that under voluntary unionism "unions will have to operate in a manner which will persuade workers to join their organisation " (Bolger, 1983, p.23), and that they will do so by providing "good service", rather than resorting to coercion. While some may argue that under voluntary unionism the "good service" will be benefits - wages, conditions, union holiday houses, union educational scholarships etc. - others have different interpretations. Hare (1946) considers that under compulsory unionism -

The spirit of a crusade for social progress which used to actuate the great majority of union secretaries has now often given place to a complacent acceptance of the situation in which the organisation will maintain itself (pp. 198-9).

Hare condemns professional union secretaries, as he feels they -

..have developed a vested interest in social discord, and have no aim other than to maintain their power by getting for the members of their union higher pay, shorter hours, and better conditions. Unless these aims are coupled with a sincere desire for social progress and a constant endeavour to educate the members of a union to take their place in industry as responsible citizens, they become artificial sources of social conflict, because they carry with them no genuine desire for a remedy (p.199).

Hare's views are worth quoting as they illustrate the subjective and idiosyncratic nature of many arguments concerning compulsory unionism. This writer believes that the vast majority of workers would be more inclined to rate the attainment of "higher pay, shorter hours and better conditions" rather than the pursuit of "social progress", as "good service". 
(6) makes management negotiations more useful since the union represents all workers

This proposition is frequently supported as being factually accurate. Thus Douglas (1983), now President of the Council of Trade Unions, wrote that the fact that clauses supporting compulsory unionism were inserted in awards and agreements -

signifies that employers and workers representatives all desire its inclusion. For the employers this may be either a recognition of the stability which results from one organisation covering all workers and/or the realisation that the overwhelming proportion of union members support its inclusion (p.31)

One would suppose that pragmatic managers would tend to agree, both with this and with the third proposition.

(7) legitimately upholds the principle of "user pays"

This proposition is frequently put by unionists and is the most common argument in favour of compulsory unionism. The rationale is clear-cut -

to accept the advantages and rights achieved by their (the unions) struggle without being a member and contributing to the funds is unfair; thus freedom not to join a union is freedom from paying union subscriptions ... to take a free ride on the backs of one's fellow worker (Szakats, 1972, p.327).

Harbridge and Webber (1987) point out that this user pays principle was supported by the Labour Government in its 1984 election manifesto saying it would support what was in effect compulsory unionism, recognizing that "those who gain should contribute to the cost of that gain" (p.81). In order to test managerial attitudes, the proposition was deliberately framed to state that it "legitimately" upheld user pays.

\section{Results}

The numbers and percentages of managers who agreed or disagreed with the 7 propositions concerning the impact of compulsory unionism together with their views as to what should be done about compulsory unionism are given in Table 2 below. To simplify the presentation, categories have been collapsed to indicate those who strongly disagree $(1,2 / 7)$, are neutral $(3,4,5 / 7)$ or who strongly agree $(6,7 / 7)$.

With regard to the mean responses, there was strong agreement for propositions 4 and 5 - that compulsory unionism is an unwarranted infringement on human freedom, and that it results in unions not giving good services. There was strong disagreement with propositions 1 and 3 - that it reduces militancy, and that it reduces conflict within the workforce. In effect, therefore, the managers agreed with propositions which were basically anti-compulsory unionism, and disagreed with those that, from a managerial viewpoint, would be most favourable to compulsory unionism. The average responses to the other three propositions were much less definite.

With these overall negative attitudes to compulsory unionism, the responses to the final questions were predictable. There was strong agreement that compulsory unionism should be discouraged and strong disagreement that it be encouraged. Not surprisingly, tests revealed a high negative correlation $(-.89)$ between these responses. There was a very weak negative response to the proposal that compulsory unionism be tolerated when it occurs.
Table 2: Attitudes and beliefs towards compulsory unionism $(\mathrm{N}=461)$

\begin{tabular}{cccc} 
& Strongly & & Strongly \\
Disagree & & Agree \\
& $(1-2)$ & $(3-5)$ & $(6-7)$ \\
\hline
\end{tabular}

Compulsory unionism (through the "closed shop"):

1) reduces union militancy

2) strengthens the union movement through increased membership

3) reduces conflict with the workforce

4) is an unwarranted infringement on human freedom

5) results in unions not bothering to provide good service for their members

6) makes management-union negotiations more useful since the union represents all workers

7) legitimately upholds the principle of "user pays"

\begin{tabular}{cccc}
67 & 19 & 14 \\
$*$ mean $=2.56$ & \multicolumn{2}{r}{ s.d. $=$} & 1.87 \\
& & \\
27 & 28 & 44 \\
*mean $=4.48$ & & s.d. $=$ & 2.16
\end{tabular}

53
$*$ mean $=3.02$

$31 \quad 16$

13

s.d. $=1.87$

$*_{\text {mean }}=5.49$

S.d. $=1.93$

13

$*_{\text {mean }}=5.16$

$31 \quad 57$

33

$40 \quad 27$

$*$ mean $=3.86$

s.d. $=1.97$

38

$45 \quad 18$

$*$ mean $=3.45$

s.d. $=1.82$

8) should be encouraged

$24 \quad 13$

$*_{\text {mean }}=2.56$

s.d. $=1.89$

9) should be discouraged

$24 \quad 60$

$*$ mean $=5.24$

s.d. $=2.04$

10) should be neither encouraged nor discouraged - but tolerated if it occurs

36
$*$ mean $=3.52$

$45 \quad 19$

* calculated on total figures, not collapsed

\section{Discussion}

There are a number of issues which need to be explored with respect to the above results. The issues are the extent to which:

(1) managerial attitudes are consistent with regards the propositions;

(2) demographic variables can explain differences in attitudes;

(3) the timing of the data collection affects the results. 


\section{Managerial consistency}

The attitude scores for the 461 managers for the 7 propositions and the three "overall" questions were correlated. The results showed that 6 of the 7 propositions and the two general questions as to whether compulsory unionism be encouraged or discouraged intercorrelated to a reasonable degree. Most correlation coefficients were in the order of 0.2 to 0.5 . Although these are all statistically highly significant $(0.18$ is significant at .001$)$, only one correlation coefficient was very high - that between the two general questions which was 0.89 . The level of correlation indicates a degree of consistency, but not a startlingly high level.

The proposition which did not inter-correlate was the second one (that compulsory unionism strengthens the union movement through increased membership), along with the third general question (that compulsory unionism be tolerated if it occurs).

Proposition 2 may be a maverick in that some managers could have had difficulty clarifying what the implications were in agreeing or disagreeing. Agreement with some of the propositions $(1,3,6$ and 7) clearly indicates a favourable attitude to compulsory unionism. Agreement with others (4 and 5) clearly indicates an unfavourable attitude. However, agreement with proposition 2 does not necessarily indicate either a favourable or an unfavourable attitude.

\section{Demographic variables}

Statistical tests were performed on the data to determine whether any demographic variable could explain differences in attitudes. It was anticipated that one variable would produce significant results - namely whether the manager was (a) a personnel/industrial relations manager, (b) in another functional area or (c) was in general management. The rationale was that industrial relations managers, although equally subject to media propaganda, would be more pragmatic, aware of the advantages to managers of compulsory unionism and hence more supportive. However, simple statistical testing (chi-square) revealed no difference in attitude to the 7 propositions. Industrial relations managers did prove to be less extreme in their opposition to compulsory unionism in general, being more inclined to a neutral stance.

Of course, the fact that one managerial group has statistically significantly differen views, does not necessarily mean that it was the job function which was the crucial variable. For example, the size of organisation may explain the differences - and a higher percentage of personnel/industrial relations managers may work for very large organisations. To test this, regression analysis was performed, using all the demographic information as independent variables, with the responses to the view that compulsory unionism be encouraged as dependent.

Stepwise selection of variables was then used to see if any one, or small number, of variables can explain the differences. In no case did any variable account for more than a small amount of variation. Thus, counter to the preconceived view of the author that industrial relations managers would be more pragmatic than general managers or those in other functions and have significantly more supportive views towards compulsory unionism, this proved not to be the case. Managerial attitudes appear not to be related to any particular variable.

Timing of the data collection

The data on which this paper is based were collected in 1984-5, the brief period of voluntary unionism. This fact in itself may affect results, although it is submitted other variables would have much more impact.

Voluntary unionism was introduced by the National Government in February 1984 - a government with a paper thin majority and which was in danger of losing that majority while it was also losing public support. Hence a Labour victory later in 1984 seemed highly probable, if not a total certainty. The Labour Opposition made it clear it would revert back to compulsory unionism once it gained office. Hence, it was obvious to many and should have been clear to all, that the period in 1984 was "unreal". The tacit acceptance by unions of the measures simply reflected the knowledge that voluntary unionism was a temporary measure and the fact that strike action at the time would hurt Labour's chances.

It is submitted that the major influence on managerial attitudes has been the effect on unions of the economic conditions, and also the consequences of legislative changes. Unions have been severely affected by the high level of unemployment, and the closely related threats of redundancy, which has weakened their relative power position. Legislative changes - affecting the registration of unions, the availability of arbitration and threats to the rational award system have also diverted many unions from their traditional stances. Coupled with this has been the attacks on the concept of compulsory unionism by the National Party and the NZEF. While this writer suspects the motives behind the attacks were political and for tactical reasons (keeping the unions diverted), they have also contributed both to the general propaganda, and emphasised the tactical advantages in continued sniping at the union movement.

\section{Conclusions}

This study has revealed strong feelings against compulsory unionism from a widespread sample of New Zealand managers. Given the universal acceptance of compulsory unionism from 1961 to 1984 , the managers surveyed apparently see surprisingly few advantages. Possibly managers have always disliked the concept, but calculated the cost in opposing it was too high, and rationalised that even if it was not a "good thing", it was at least a "pragmatic" choice.

The propositions examined in this study are clearly neither supported nor unsupported by the results - nor was there any attempt to do so. However the study does indicate a strong feeling of opposition to compulsory unionism which will probably result in further propaganda against the continuation of compulsory unionism through the union membership clause. It is unlikely however that in the short term there will be wide-scale opposition by management assessors to the clause's insertion - given that under current law this would simply result in a ballot. Experience in the 1970's indicates that ballots would result in retention of compulsory unionism. Hence management opposition would only be for the purpose of deliberate specific provocation. The more likely scenario is non-specific sniping at the union movement with general calls for "labour market flexibility" and voluntary unionism.

\section{References}

Bolger, Hon J B (1983) Reason for voluntary unionism in 1983. In Brosnan (1983).

Brosnan, P (ed) (1983) Voluntary unionism Proceedings of a seminar, Industrial Relations Centre, Victoria University of Wellington.

Campbell, G (1984) Compulsory unionism makes a comeback Listener 3 November:1819.

Cordova, E and Ozaki, M (1980) Union security arrangements: an international overview International labour review 119(1):19-38. 
Douglas, K G (1983) Implications of voluntary unionism: the union perspective. In Brosnan (1983).

Geare, A J (1984) Making unionism voluntary Public sector 7(2-3):20-23.

Geare, A J (1988) The system of industrial relations in New Zealand 2nd ed, Wellington, Butterworths.

Hanson, C, Jackson, S and Miller, D (1982) The closed shop Aldershot, Gower.

Harbridge, R and Walsh, P (1985) Legislation prohibiting the closed shop in New Zealand: its introduction and consequences Journal of industrial relations 27(2):191-206.

Harbridge, R and Webber, S (1987) Trends in official union membership:1983-85 New Zealand journal of industrial relations 12(2):81-88.

Hare, A E C (1946) Report on industrial relations in New Zealand Wellington, Victoria University.

Howells, J M (1983) For or against compulsory unionism? Recent ballots in New Zealand International labour review 122(1):95-110.

Roots, P (1986) Collective bargaining: opportunities for a new approach Warwick papers in industrial relations No 5 University of Warwick, Coventry.

Roth, H (1973) Trade unions in New Zealand Wellington, AH and AW Reid.

Szakats, A (1972) Compulsory unionism: a strength or weakness Alberta law review 10:313-343.

Woods, N S (1975) Industrial relations: a search for understanding Wellington, Hicks Smith and Sons. 